\title{
Perubahan Komposisi Gulma pada Sistem Tumpangsari Padi Gogo dengan Kedelai di Lahan Pasir Pantai
}

\author{
Weeds Composition Change Under Intercropping System \\ of Upland Rice with Soybean in Coastal Sandy Area
}

\section{Fajrin Pramana Putra $^{{ }^{*}}$, Prapto Yudono ${ }^{2}$, dan Sriyanto Waluyo ${ }^{2}$}

${ }^{1}$ Program Studi Agronomi, Fakultas Pertanian, Universitas Gadjah Mada

JL. Flora, Bulaksumur, Caturtunggal, Kec. Depok, Kabupaten Sleman, Daerah Istimewa Yogyakarta 55281, Indonesia

${ }^{2}$ Departemen Budidaya Pertanian, Fakultas Pertanian, Universitas Gadjah Mada

JL. Flora, Bulaksumur, Caturtunggal, Kec. Depok, Kabupaten Sleman, Daerah Istimewa Yogyakarta 55281, Indonesia

Diterima 21 Agustus 2017/Disetujui 17 November 2017

\begin{abstract}
Weeds can reduce upland rice yields in coastal sandy area. Density and growth of weeds can be controlled and reduced by an intercropping system between upland rice with soybeans. The study aimed to determine the weeds composition change and weeds biomass in various crop proportions of upland rice and soybean under intercropping. The research was conducted from December 2016 until March 2017, at coastal sandy soil of Samas, Bantul, Yogyakarta (800'03.5 'S and 110 15'20.1 '”E). This study used a complete randomized block design (RCBD) with one factor and three replications. The treatments were crop proportions of upland rice and soybean under intercropping with 6 levels, such as 100:0 (upland rice monoculture), 80:20, 60:40, 40:60, 20:80, and 0: 100 (soybean monoculture). The results showed that there was weeds composition changes due to setting crop proportions of upland rice and soybean under intercropping at coastal sandy soil. Weed of sedges, grass, and broadleaf were found throughout the experimental plots, but varied in number and type of weeds among experimental plots. Weeds condition differed among the soybean proportion treatments $<40 \%$ and $\geq 40 \%$. The average community coefficient value was $<75 \%$ which was dominated by Digitaria nuda and Eragrostis tenella under soybean proportion treatments $<$ $40 \%$, and Ludwigia parviflora and Amaranthus lividus under soybean proportion treatments $\geq 40 \%$. The linear model was established between the increase of soybean proportion to a decrease in dry weight of weeds as $Y=-0.6624 X+67.699 ; R^{2}$ $=0.7224$ ).
\end{abstract}

Keywords: crops proportion, intercropping, weeds community

\section{ABSTRAK}

Gulma merupakan tumbuhan yang dapat menurunkan hasil produksi padi gogo di lahan pasir pantai. Pertumbuhan gulma dapat dikendalikan dan dikurangi kepadatannya melalui sistem tumpangsari antara padi gogo dengan kedelai. Penelitian bertujuan untuk mengetahui perubahan komposisi dan biomasa gulma di berbagai pengaturan proporsi tanaman pada tumpangsari padi gogo dengan kedelai. Penelitian dilaksanakan pada bulan Desember 2016 sampai dengan Maret 2017 di lahan pasir pantai Samas, Bantul, Daerah Istimewa Yogyakarta (800'03.5”'LS dan 110¹5'20.1”BT). Penelitian menggunakan rancangan acak kelompok lengkap (RAKL) dengan satu faktor dan tiga ulangan. Faktor perlakuan yang diujikan yaitu proporsi tanaman pada tumpangsari padi gogo dengan kedelai dengan 6 taraf, yaitu 100:0 (monokultur padi gogo), 80:20, 60:40, 40:60, 20:80, dan 0:100 (monokultur kedelai). Hasil penelitian menunjukkan bahwa terjadi perubahan komposisi gulma akibat pengaturan proporsi tanaman pada sistem tumpangsari padi gogo dengan kedelai di lahan pasir pantai. Gulma jenis teki, rumput, dan daun lebar ditemukan di seluruh petak percobaan, dengan jumlah dan jenis gulma yang berbeda antar petak percobaan. Keadaan vegetasi gulma berbeda antara proporsi tanaman kedelai $<40 \%$ dengan $\geq 40 \%$, nilai koefisien komunitas rata-rata $<75 \%$, yang didominasi gulma Digitaria nuda dan Eragrostis tenella pada proporsi tanaman kedelai $<40 \%$, dan gulma Ludwigia parviflora dan Amaranthus lividus pada proporsi tanaman kedelai $\geq$ 40\%. Hubungan regresi linier terbentuk antara peningkatan proporsi kedelai terhadap penurunan bobot kering gulma, yakni $\left.Y=-0.6624 X+67.699 ; R^{2}=0.7224\right)$.

Kata kunci: komunitas gulma, proporsi tanaman, tumpangsari

\footnotetext{
* Penulis untuk korespondensi. e-mail: fajrin.pramana.p@gmail.com
} 


\section{PENDAHULUAN}

Permintaan bahan pangan terus meningkat seiring dengan terjadinya peningkatan jumlah penduduk Indonesia sebesar $1.17 \%$ per tahun (Badan Pusat Statistik, 2016). Padi gogo merupakan salah satu tanaman pangan penting yang perlu ditingkatkan produksinya karena baru menyumbang sebesar 5.28\% dari total produksi padi nasional (Kementan, 2017). Mengingat adanya fenomena peningkatan jumlah penduduk di Indonesia, peningkatan produksi padi nasional melalui padi gogo akan menjadi penting mengingat areal luas sawah mengalami penurunan sebesar $2.52 \%$ pada periode 2012-2013 akibat alih fungsi lahan (Badan Pusat Statistik, 2014).

Peningkatan produksi padi gogo dapat terwujud melalui upaya ekstensifikasi dengan memanfaatkan lahan pasir pantai. Indonesia merupakan negara kepulauan yang mempunyai potensi luas lahan pasir pantai sebesar 1,060,000 ha yang dapat dimanfaatkan sebagai lahan pertanian (Saparso et al., 2009). Pada umumnya, lahan pasir pantai merupakan lahan marginal yang mempunyai banyak faktor pembatas yang berupa tingkat kesuburan yang sangat rendah dan laju infiltrasi yang sangat tinggi (Rajiman et al., 2008; Yu et al., 2016). Saat ini lahan pasir pantai dimanfaatkan oleh praktisi pertanian menjadi lahan produktif yang mampu memberikan hasil yang optimal dengan beberapa masukan teknologi untuk meningkatkan kesuburan tanahnya.

Pengelolaan lahan pasir pantai untuk budidaya tanaman dapat dilakukan dengan pemberian bahan pembenah tanah berupa tanah sawah dan pupuk kandang (Rajiman et al., 2008). Pemberian pembenah tanah berupa pupuk kandang dan tanah sawah pada lahan pasir pantai memicu pembentukan dan perubahan komunitas gulma. Faktor-faktor yang mempengaruhi keragaman komunitas gulma adalah faktor lingkungan, seperti faktor klimatik, edafik, dan biotik (Mangoensoekarjo dan Soejono, 2015).

Berdasarkan penelitian Fitriana et al. (2013) terjadi perubahan komunitas gulma di lahan yang diaplikasikan bahan pembenah tanah seperti pupuk kandang. Gulma yang tumbuh merupakan gulma yang berasal dari biji-biji dan propagul gulma yang terdapat dalam pupuk kandang dan tanah sawah (faktor biotik). Secara umum, gulma dominan pada tanaman budidaya di lahan pasir pantai merupakan jenis gulma berdaun sempit dan tergolong dalam tumbuhan C4 seperti: Eleusine indica (L.) Gaertn., Cyperus rotundus L., Cyperus iria L., dan Digitaria nuda Schumach (Ilham, 2014). Gulma tersebut dapat menimbulkan gangguan bagi tanaman budidaya. Gulma merupakan penyebab utama kehilangan hasil tanaman budidaya lewat persaingan cahaya, air, nutrisi, $\mathrm{CO}_{2}$, ruang dan lain-lainnya. Hasil penelitian menunjukkan bahwa pengendalian gulma yang terlambat dapat menurunkan hasil padi gogo sampai 35\% (Toure et al., 2013).

Salah satu upaya untuk mengatasi gulma dapat dilakukan dengan menerapkan sistem tumpangsari. Selain itu, sistem tumpangsari merupakan salah satu metode untuk meningkatkan produktivitas lahan dan mengurangi risiko kegagalan dalam produksi tanaman. Sistem tumpangsari dengan tanaman yang memiliki morfologi daun yang lebar seperti legume, mampu menekan pertumbuhan gulma (Eskandari dan Kazemi, 2011; Gharineh dan Moosavi, 2010; Khan et al., 2012). Jamshidi et al. (2013) menjelaskan bahwa terjadi pengurangan kepadatan dan perubahan komunitas gulma di bawah tegakan tanaman sistem tumpangsari jagung (Zea mays) - kacang tunggak (Vigna unguiculata) akibat adanya penutupan tanah yang sempurna oleh tajuk tanaman kacang tunggak. Perubahan komunitas gulma terjadi selama proses pertumbuhan tanaman yang disebabkan oleh sinar matahari yang mampu menembus sampai ke permukaan tanah. Awal pertumbuhan tanaman jagung-kacang tanah pada sistem tumpangsari, gulma teki, dan rumput lebih mendominasi karena tajuk tanaman belum tumbuh secara optimal. Sinar matahari dapat menembus sampai permukaan tanah pada awal pertumbuhan tanaman sehingga sangat mendukung pertumbuhan teki dan rumput. Pada saat terjadi penutupan tanah secara sempurna, gulma jenis daun lebar lebih mendominasi karena lebih tahan terhadap naungan, demikian juga dengan kelembaban yang semakin tinggi memungkinkan makin banyaknya biji yang tersimpan dalam tanah berkecambah sementara dari golongan spesies rumputan relatif tetap (Pasau et al., 2008). Tujuan dari penelitian ini adalah untuk mengetahui komposisi dan biomasa gulma di berbagai pengaturan proporsi tanaman pada tumpangsari padi gogo dengan kedelai.

\section{BAHAN DAN METODE}

Penelitian ini dilaksanakan pada bulan Desember 2016 sampai dengan Maret 2017 di lahan pasir pantai Samas, Bantul, Daerah Istimewa Yogyakarta $\left(8^{\circ} 00^{\prime} 03.5^{\prime}\right.$ 'LS dan $110^{\circ} 15^{\prime} 20.1$ 'BT). Penelitian ini menggunakan rancangan acak kelompok lengkap (RAKL) dengan satu faktor perlakuan dan tiga kali ulangan. Faktor perlakuan yaitu proporsi tanaman (Gambar 1) yang meliputi: a. Monokultur padi gogo (100:0), b. Monokultur kedelai (0:100), c. Tumpangsari $80 \%$ padi gogo $+20 \%$ kedelai $(80: 20)$, d. Tumpangsari $60 \%$ padi gogo $+40 \%$ kedelai $(60: 40)$, e. Tumpangsari $40 \%$ padi gogo $+60 \%$ kedelai (40:60), dan $\mathrm{f}$. Tumpangsari $20 \%$ padi gogo $+80 \%$ kedelai $(20: 80)$.

Penanaman padi gogo dan kedelai dengan menggunakan jarak tanam yang sama yaitu $20 \mathrm{~cm}$ x 20 $\mathrm{cm}$. Selama masa penanaman padi gogo dan kedelai tidak dilakukan pengendalian gulma. Pengamatan gulma dilakukan setelah tanaman berumur 9 minggu setelah tanam. Identifikasi jenis gulma dilakukan dengan pengambilan sampel gulma menggunakan kerangka kawat berbentuk bujur sangkar berukuran $60 \mathrm{~cm}$ x $60 \mathrm{~cm}$ dengan systematic random sampling (Mangoensoekarjo dan Soejono, 2015). Variabel pengamatan yang dilakukan antara lain: sum dominance ratio (SDR) gulma, nilai koefisien komunitas gulma (C), cahaya terusan ke permukaan tanah, dan bobot kering gulma.

Perhitungan koefisien komunitas gulma (C) dilakukan untuk mengetahui keragaman komunitas gulma antar lokasi berdasarkan Mangoensoekarjo dan Soejono (2015):

$\mathrm{C}=((2 \times \mathrm{w}) /(\mathrm{a}+\mathrm{b})) \times 100 \%$. 


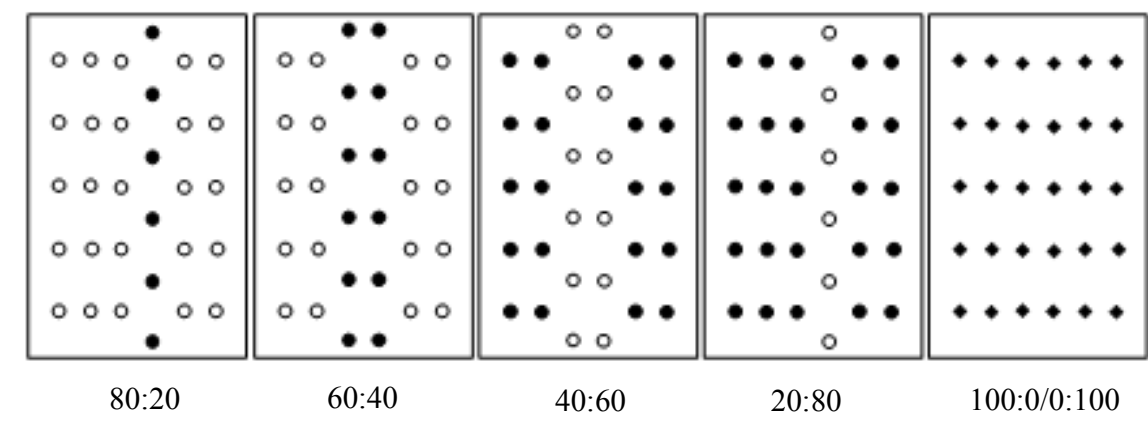

Kedelai $\bigcirc$ Padi gogo Kedelai dan atau padi gogo pada sistem monokultur

Gambar 1. Pengaturan proporsi tanaman padi gogo dan kedelai secara tumpangsari dan monokultur

Keterangan: $\mathrm{C}=$ koefisien komunitas gulma, $\mathrm{a}+\mathrm{b}=$ jumlah SDR semua jenis gulma di lokasi A dan $\mathrm{B}, \mathrm{w}=$ jumlah SDR yang rendah dari setiap pasang jenis gulma dari dua lokasi.

Terusan cahaya ke permukaan tanah diperoleh dengan melakukan pengukuran intensitas cahaya pada bagian atas dan bawah tajuk tanaman menggunakan lux meter model LX-1330B. Kemudian dihitung berdasarkan rumus sebagai berikut:

$\mathrm{CT}=(\mathrm{ICb} / \mathrm{ICa}) \times 100 \%$.

Keterangan: $\mathrm{CT}=$ cahaya terusan ke permukaan tanah $(\%), \mathrm{ICa}=$ intensitas cahaya di atas tajuk tanaman (lux), dan $\mathrm{ICb}=$ intensitas cahaya di bawah tajuk tanaman (lux).

Data cahaya terusan ke permukaan tanah dan bobot kering gulma yang diperoleh selanjutnya dianalisis dengan menggunakan analisis ragam (ANOVA) berdasarkan rancangan acak kelompok lengkap dengan menggunakan ms. Excel macro add-ins (DSAASTAT versi 1.101) pada tingkat kesalahan 5\% dan akan diuji lanjut dengan uji beda nyata terkecil (BNT) jika hasil analisis ragam menunjukkan beda nyata (Onofri dan Pannacci, 2014).

\section{HASIL DAN PEMBAHASAN}

Cahaya Terusan ke Permukaan Tanah Akibat Pengaturan Proporsi Tanaman

Berdasarkan hasil sidik ragam persentase cahaya terusan ke permukaan tanah menunjukkan bahwa proporsi tanaman memberikan pengaruh nyata terhadap persentase cahaya terusan ke permukaan tanah. Proporsi tanaman 0:100 mampu menahan cahaya terusan sampai ke permukaan tanah dengan baik kemudian diikuti oleh proporsi tanaman 20:80, 40:60, dan 60:40 (Gambar 2).

Arsitektur kanopi dan pengaturan baris menjadi faktor penentu lolosnya cahaya sampai permukaan tanah (Gao et al., 2010). Daun padi gogo termasuk jenis daun sempit yang tumbuh secara vertikal sehingga daun padi gogo tidak mampu dalam menahan cahaya yang sampai ke permukaan tanah. Daun kedelai merupakan jenis daun lebar yang tumbuh secara horizontal sehingga mampu menyekap cahaya secara optimal dan mampu mengurangi cahaya yang sampai ke permukaan tanah. Menurut Liu et al. (2017), hasil sekapan cahaya pada tanaman jagung dan kedelai dengan pengaturan baris 2:2 lebih tinggi dibandingkan dengan sistem monokulturnya, sehingga mampu mengurangi cahaya terusan ke permukaan tanah. Cahaya terusan ke permukaan tanah ini selanjutnya akan memberikan dampak bagi pertumbuhan gulma di area pertanaman.

\section{Struktur dan Komposisi Gulma}

Berdasarkan jenisnya secara keseluruhan didapatkan 10 jenis gulma berdaun lebar, 7 jenis gulma rumput, dan 3 jenis gulma golongan teki (Tabel 1). Komposisi dan jumlah jenis gulma yang terdapat pada masing-masing petak perlakuan cukup beragam. Jumlah jenis berkisar 13 jenis gulma pada monokultur kedelai (0:100) sampai dengan 18 jenis gulma pada monokultur padi gogo (100:0). Jumlah jenis gulma yang banyak pada monokultur padi gogo (100:0) diduga akibat cahaya terusan pada petak percobaan tersebut tergolong tinggi (35.5\%) sehingga biji gulma mampu berkecambah. Biji gulma membutuhkan cahaya untuk dapat berkecambah berkaitan dengan rangsangan oleh cahaya pada fitokrom. Fitokrom adalah pigmen yang mengendalikan fotomorfogenesis pada tumbuhan tingkat tinggi, merupakan faktor yang menyebabkan biji terangsang untuk berkecambah apabila terkena cahaya.

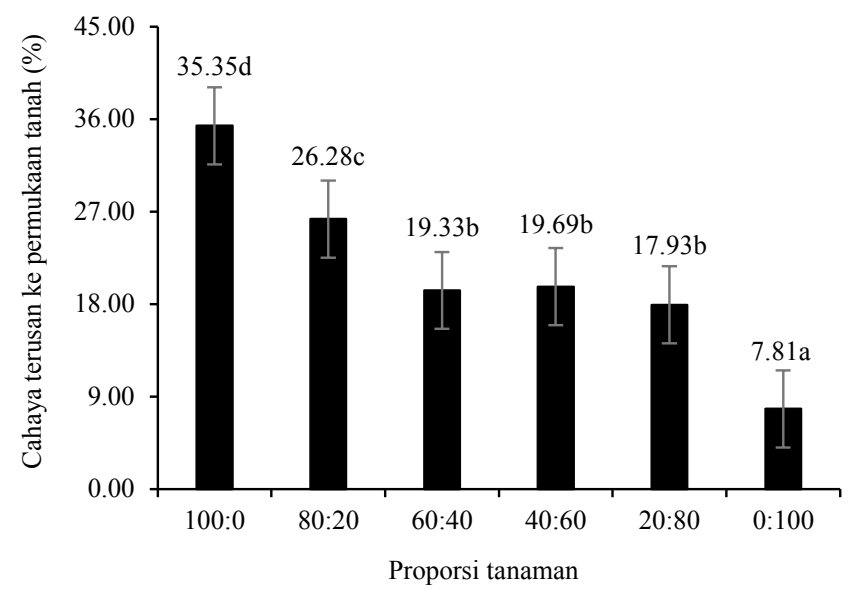

Gambar 2. Cahaya terusan di permukaan tanah akibat pengaturan pengaturan proporsi tanaman pada sistem tumpangsari padi gogo dengan kedelai 
Pigmen ini memacu perkecambahan biji bila berada pada kondisi cahaya merah jauh dengan panjang gelombang 730 $\mu \mathrm{m}$ dan cahaya merah dengan panjang gelombang $680 \mu \mathrm{m}$ (Soejono, 2005).

Apabila dilihat dari strukturnya, gulma daun lebar lebih mendominasi karena memiliki jumlah jenis yang muncul lebih banyak di setiap petak perlakuan (Tabel 1). Gulma daun lebar mampu mendominasi karena mayoritas perkembangbiakannya dengan biji. Biji-biji yang ada di dalam tanah terangkat pada saat pengolahan tanah dan berkecambah apabila kebutuhannya akan air dan cahaya tercukupi. Gulma jenis teki khususnya Cyperus rotundus yang memiliki alat perkembangbiakan vegetatif dapat dikendalikan pada saat pengolahan tanah sehingga perkecambahannya dapat ditekan.

Komposisi Jenis dan Perubahan Gulma Akibat Pengaturan Proporsi Tanaman pada Sistem Tumpangsari Padi Gogo dengan Kedelai

Pengaturan proporsi tanaman 100:0 (monokultur padi gogo) terdapat 18 jenis gulma yang tumbuh (Tabel 2). Gulma-gulma yang dominan adalah Digitaria nuda (SDR 16.11\%), Eragrostis tenella (SDR 10.60\%), dan Dactyloctenium aegyptium (SDR 9.39\%) yang termasuk gulma rumput semusim golongan $\mathrm{C} 4$. Hal yang sama terjadi pada proporsi tanaman 80:20 yang didominasi oleh jenis gulma rumput semusim golongan $\mathrm{C} 4$ yaitu Digitaria nuda (18.86\%), Eragrostis tenella $(18.86 \%)$, Eleusine indica (11.36\%), dan Dactyloctenium aegyptium (11.36\%) (Tabel 2). Gulma yang dominan setelah proporsi tanaman kedelai ditingkatkan dari $40 \%$ sampai $100 \%$ adalah Ludwigia parviflora (C3) dan Amaranthus lividus (C4) termasuk gulma daun lebar semusim. Nilai SDR gulma Ludwigia parviflora dan Amaranthus lividus pada perlakuan 60:40, 40:60, 20:80, dan 0:100 masing-masing adalah 19.24\%; $18.84 \% ; 18.67 \% ; 26.86 \%$ dan $16.66 \% ; 17.41 \%$; $23.89 \%$; $18.75 \%$ (Tabel 2).

Pertambahan dan berkurangnya jenis serta perubahan komposisi gulma terjadi setelah adanya pengaturan proporsi tanaman pada sistem tumpangsari padi gogo dengan kedelai. Antara proporsi tanaman 60:40, 40:60, 20:80, dan 0:100, jenis gulma yang dominan sama meskipun jumlah jenis gulmanya berbeda dan komposisinya yang berbeda. Sebagai contoh pada perlakuan 40:60 terdapat gulma Echinochloa crus-galli, yang tidak ditemukan pada perlakuan 60:40, 20:80, dan 0:100. Gulma Oldenlandia corymbosa tidak diketemukan pada perlakuan 0:100, tetapi ditemukan pada perlakuan 60:40, 20:80, dan 0:100 (Tabel 2).

Penelitian ini menunjukkan bahwa gulma rumput semusim golongan $\mathrm{C} 4$ mendominasi pada petak perlakuan 100:0 (monokultur padi gogo) dan 80:20, sedangkan pada perlakuan lainnya bergeser pada golongan daun lebar golongan $\mathrm{C} 3$ yang lebih mendominasi. Hal ini disebabkan pada perlakuan proporsi kedelai $\geq 40 \%$, cahaya terusan ke permukaan tanah dibawah 20\% sehingga teki dan rumput yang termasuk dalam golongan $\mathrm{C} 4$ terhambat pertumbuhannya karena membutuhan cahaya yang cenderung lebih tinggi untuk melakukan proses fotosintesis. Berbeda dengan gulma golongan daun lebar yang toleran terhadap kondisi cahaya rendah, sehingga mampu mendominasi saat terjadi pengurangan sinar matahari. Menurut Marsal et al. (2015) bahwa gulma teki dan rumput secara umum termasuk dalam golongan $\mathrm{C} 4$ yang memiliki titik kompensasi cahaya yang tinggi, sedangkan gulma daun lebar mayoritas termasuk dalam golongan C3 yang memiliki titik kompensasi cahaya rendah. Dengan demikian, apabila gulma teki dan rumput tidak mendapat intensitas cahaya yang cukup maka akan terhambat pertumbuhannya, sedangkan gulma daun lebar masih tetap tumbuh baik karena titik kompensasi cahayanya rendah.

\section{Koefisien Komunitas Gulma}

Koefisien komunitas gulma berguna untuk membandingkan dua komunitas atau dua macam vegetasi dari dua daerah (Marsal et al., 2015). Koefisien komunitas gulma antara proporsi tanaman 100:0 (monokultur padi gogo) dengan 60:40, 40:60, 20:80, dan 0:100<75\%, artinya komunitas gulma pada proporsi tanaman 100:0 dengan 60:40, 40:60, 20:80, dan 0:100 memiliki perbedaan. Namun, koefisien komunitas gulma pada proporsi tanaman 100:0 dengan 80:20 > 75\%, yang artinya komunitas gulma pada proporsi tanaman tersebut sama (Tabel 3). Adanya perbedaan komunitas gulma antara proporsi tanaman 100:0 dan 80:20 dengan proporsi tanaman kedelai $\geq 40 \%$ menunjukkan adanya perubahan komposisi gulma. Pada proporsi tanaman padi $\geq 80 \%$ lebih didominasi oleh gulma rumput semusim golongan C4 (Digitaria nuda) sedangkan pada proporsi tanaman kedelai $\geq 40 \%$ lebih didominasi oleh gulma daun lebar semusim golongan C3 (Ludwigia parviflora).

Pengamatan di lapangan menunjukkan perbedaan komunitas gulma antara proporsi tanaman kedelai $\leq 20 \%$

Tabel 1. Komposisi gulma di beberapa pengaturan proporsi tanaman pada sistem tumpangsari padi gogo dengan kedelai

\begin{tabular}{|c|c|c|c|c|c|c|c|}
\hline \multirow{2}{*}{ Golongan gulma } & \multicolumn{6}{|c|}{ Jumlah spesies gulma pada tiap petak percobaan } & \multirow{2}{*}{ Total jenis gulma } \\
\hline & 100:0 & $80: 20$ & $60: 40$ & $40: 60$ & $20: 80$ & $0: 100$ & \\
\hline Daun lebar & 9 & 7 & 8 & 6 & 8 & 7 & 10 \\
\hline Rumput & 7 & 7 & 3 & 6 & 5 & 5 & 7 \\
\hline Teki & 2 & 2 & 1 & 1 & 2 & 1 & 3 \\
\hline Jumlah & 18 & 16 & 12 & 13 & 15 & 13 & 20 \\
\hline
\end{tabular}


Tabel 2. Nilai SDR (\%) masing-masing jenis gulma di berbagai pengaturan proporsi tanaman pada sistem tumpangsari padi gogo dengan kedelai

\begin{tabular}{|c|c|c|c|c|c|c|c|c|c|}
\hline No & Nama gulma & $\mathrm{Gol}^{\mathrm{a}}$ & $\mathrm{DH}$ & $100: 0$ & $80: 20$ & $60: 40$ & $40: 60$ & $20: 80$ & $0: 100$ \\
\hline \multicolumn{10}{|c|}{ Golongan gulma tekian } \\
\hline 1 & Cyperus compressus $\mathrm{L}$. & $\mathrm{C} 4$ & $\mathrm{~S}$ & 0.00 & 1.77 & 0.00 & 0.00 & 0.00 & 0.00 \\
\hline 2 & Cyperus iria $\mathrm{L}$. & $\mathrm{C} 4$ & S & 6.80 & 4.72 & 3.56 & 4.39 & 5.98 & 5.32 \\
\hline 3 & Cyperus rotundus $\mathrm{L}$. & $\mathrm{C} 4$ & $\mathrm{~T}$ & 4.10 & 0.00 & 0.00 & 0.00 & 1.62 & 0.00 \\
\hline \multicolumn{10}{|c|}{ Golongan gulma rumputan } \\
\hline 4 & Dactyloctenium aegyptium (L.) Beauv. & $\mathrm{C} 4$ & $\mathrm{~S}$ & 9.39 & 11.36 & 0.00 & 4.97 & 3.23 & 0.00 \\
\hline 5 & Digitaria nuda Schumach. & $\mathrm{C} 4$ & $\mathrm{~S}$ & 16.11 & 18.86 & 5.26 & 5.98 & 7.07 & 3.40 \\
\hline 6 & Echinochloa colona (L.) Link. & $\mathrm{C} 4$ & $\mathrm{~S}$ & 3.96 & 3.93 & 0.00 & 2.14 & 0.00 & 3.77 \\
\hline 7 & Echinochloa crus-galli (L.) P. Beauv. & $\mathrm{C} 4$ & $\mathrm{~S}$ & 1.56 & 1.59 & 0.00 & 4.47 & 0.00 & 0.00 \\
\hline 8 & Eleusine indica (L.) Gaertn. & $\mathrm{C} 4$ & $\mathrm{~S}$ & 5.07 & 11.36 & 0.00 & 6.16 & 1.59 & 2.04 \\
\hline 9 & Eragrostis tenella (Linn.) P. Beauv. & $\mathrm{C} 4$ & $\mathrm{~S}$ & 10.60 & 18.86 & 6.67 & 9.99 & 10.35 & 8.89 \\
\hline 10 & Leptochloa chinensis (L.) Nees. & $\mathrm{C} 4$ & $\mathrm{~S}$ & 5.84 & 1.59 & 3.08 & 0.00 & 3.61 & 7.14 \\
\hline \multicolumn{10}{|c|}{ Golongan gulma daun lebar } \\
\hline 11 & Amaranthus lividus L. & $\mathrm{C} 4^{\mathrm{b}}$ & $\mathrm{S}$ & 9.23 & 15.64 & 16.66 & 17.41 & 23.89 & 18.75 \\
\hline 12 & Boerhavia erecta $\mathrm{L}$. & $\mathrm{C} 3$ & $\mathrm{~S}$ & 2.48 & 5.25 & 18.63 & 8.70 & 4.02 & 5.68 \\
\hline 13 & Cleome asvera & $\mathrm{C} 3$ & $\mathrm{~S}$ & 1.55 & 0.00 & 0.00 & 0.00 & 0.00 & 0.00 \\
\hline 14 & Gynandropsis gynandra (L.) Briq. & $\mathrm{C} 3$ & $\mathrm{~S}$ & 0.00 & 1.30 & 2.32 & 0.00 & 1.55 & 2.48 \\
\hline 15 & Ludwigia parviflora Roxb. & $\mathrm{C} 3$ & $\mathrm{~S}$ & 9.17 & 7.34 & 19.24 & 18.84 & 18.67 & 26.86 \\
\hline 16 & Oldenlandia corymbosa $\mathrm{L}$. & $\mathrm{C} 3$ & $\mathrm{~S}$ & 2.78 & 3.48 & 5.74 & 5.11 & 3.41 & 0.00 \\
\hline 17 & Physalis angulata $\mathrm{L}$. & $\mathrm{C} 3$ & $\mathrm{~S}$ & 0.32 & 0.00 & 0.00 & 0.00 & 0.00 & 0.00 \\
\hline 18 & Phyllanthus niruri L. & $\mathrm{C} 3$ & $\mathrm{~S}$ & 6.45 & 3.03 & 9.81 & 5.61 & 8.24 & 4.07 \\
\hline 19 & Portulaca oleracea L. & $\mathrm{C} 4^{\mathrm{b}}$ & $\mathrm{S}$ & 3.22 & 5.07 & 6.94 & 6.23 & 5.33 & 9.49 \\
\hline 20 & Synedrella nodiflora $\mathrm{L}$. & $\mathrm{C} 3$ & $\mathrm{~S}$ & 1.37 & 0.00 & 2.09 & 0.00 & 1.45 & 2.10 \\
\hline
\end{tabular}

Sumber: ( ${ }^{\mathrm{a}}$ Waller dan Lewis, 1979; bownton, 1971)

Keterangan: $\mathrm{Gol}=$ golongan gulma; $\mathrm{DH}=$ daur hidup; $\mathrm{S}=$ semusim; dan $\mathrm{T}=$ tahunan

dengan tanaman kedelai $\geq 40 \%$ terjadi karena perubahan komposisi gulma akibat pengaturan proporsi tanaman pada sistem tumpangsari padi gogo dengan kedelai. Perubahan komposisi jenis gulma akibat adanya praktik budidaya, seperti pengolahan tanah, pemupukan, pengendalian dan karakteristik spesies gulma yang selalu mengalami perubahan komposisi untuk beradaptasi terhadap lingkungan karena aktivitas manusia (Chauhan et al., 2012).

\section{Biomassa Gulma}

Hasil sidik ragam menunjukkan bahwa pengaturan proporsi tanaman berpengaruh nyata terhadap bobot kering gulma. Bobot kering gulma pada proporsi tanaman 60:40, 40:60, 20:80, dan 0:100 (monokultur kedelai) lebih kecil dibandingkan dengan 100:0 dan 80;20 (Gambar 3). Hal ini diduga karena pada proporsi tanaman 60:40, 40:60, 20:80,

Tabel 3. Koefisien komunitas gulma (\%) di berbagai pengaturan proporsi tanaman pada sistem tumpangsari padi gogo dengan kedelai

\begin{tabular}{lcrrrrr}
\hline $\begin{array}{l}\text { Proporsi tanaman } \\
\text { Padi gogo : Kedelai }\end{array}$ & $100: 0$ & $80: 20$ & $60: 40$ & $40: 60$ & $20: 80$ & $0: 100$ \\
\hline $100: 0$ & 100.00 & 78.08 & 55.59 & 66.59 & 68.16 & 58.81 \\
$80: 20$ & & 100.00 & 58.16 & 73.33 & 65.64 & 60.78 \\
$60: 40$ & & 100.00 & 76.63 & 77.88 & 73.71 \\
$40: 60$ & & & 100.00 & 79.63 & 73.10 \\
$20: 80$ & & & & 100.00 & 76.64 \\
$0: 100$ & & & & & 100.00 \\
\hline
\end{tabular}


dan 0:100 (monokultur kedelai) mampu mempersempit ruang tumbuh gulma dan menahan cahaya matahari sampai permukaan tanah lebih dari $80 \%$. Ruang tumbuh yang sempit untuk gulma menyebabkan kalah berkompetisi dalam memperebutkan air dan unsur hara dengan tanaman padi gogo maupun kedelai. Dampak keterbatasan ruang tumbuh dan suplai energi matahari adalah berkurangnya kemampuan gulma dalam memproduksi bahan kering pada proses fotosintesis selanjutnya pertumbuhan gulma akan terhambat.

Proporsi kedelai yang tinggi menyebabkan terjadinya kompetisi terhadap ruang tumbuh dan cahaya sehingga menurunkan bobot kering gulma, sesuai pendapat Choudhary et al. (2014) bahwa terjadi penurunan bobot kering gulma pada saat dilakukan peningkatan proporsi

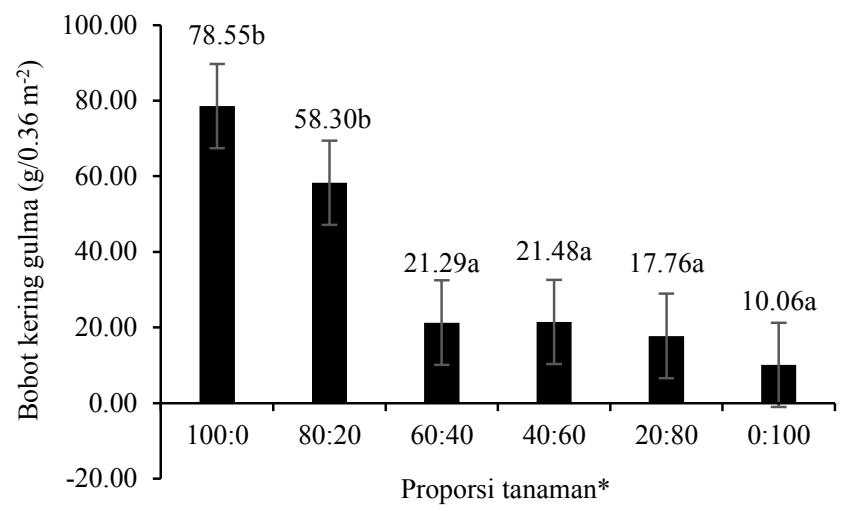

Gambar 3. Bobot kering gulma di berbagai pengaturan proporsi tanaman pada sistem tumpangsari padi gogo dengan kedelai

\section{KESIMPULAN}

Jenis gulma pada monokultur padi gogo (100:0) di lahan pasir pantai Samas, Bantul, DIY mengalami perubahan setelah diatur proporsinya menjadi 60:40, 40:60, dan 20:80. Gulma utama yang dominan pada proporsi tanaman 100:0 dan 80:20 adalah Digitaria nuda dan Eragrostis tenella merupakan gulma golongan rumput yang memiliki nilai SDR lebih tinggi dari jenis gulma yang lain pada perlakuan tersebut. Gulma dominan pada proporsi tanaman kedelai $\geq 40 \%$ (60:40, 40:60, 20:80, dan 0:100) adalah Ludwigia parviflora dan Amaranthus lividus. Keadaan vegetasi gulma pada pengaturan 100:0 dan pengaturan proporsi kedelai $\geq$ $40 \%$ berbeda, dengan nilai koefisien komunitas rata-rata $<$ $75 \%$. Peningkatan proporsi tanaman kedelai $\geq 40 \%$ dalam sistem tumpangsari mampu menghambat pertumbuhan gulma.

\section{DAFTAR PUSTAKA}

Amosse, C., M.H. Jeuffroy, F. Celette, C. David. 2013. Relay-intercropped forage legumes help to control weeds in organic grain production. Europ. J. Agro. 49: 158-167. tanaman kacang tanah. Selain itu menurut Mangoensoekarjo dan Soejono (2015) menyebutkan bahwa tanaman legume sebagai cover crop mampu tumbuh dengan cepat pada fase vegetatif sehingga dapat mempersempit ruang tumbuh untuk gulma terutama gulma teki dan rumput. Hal yang sama dikemukakan oleh Amosse et al. (2013), adanya penanaman legume cover crop pada pertanaman gandum memberikan pengaruh terhadap penurunan kepadatan dan biomasa gulma disekitar tanaman. Menurut Marsalis et al. (2010) salah satu bentuk pertumbuhan yang terhambat adalah kemampuan mengakumulasi bahan kering yang turun atau lebih rendah. Hasil uji hubungan regresi linier (Gambar 4) menunjukkan pengaruh peningkatan proporsi tanaman kedelai mampu menurunkan bobot kering gulma secara nyata $\left(\mathrm{R}^{2}=0.7224\right.$; $\mathrm{P}=0.0001)$.

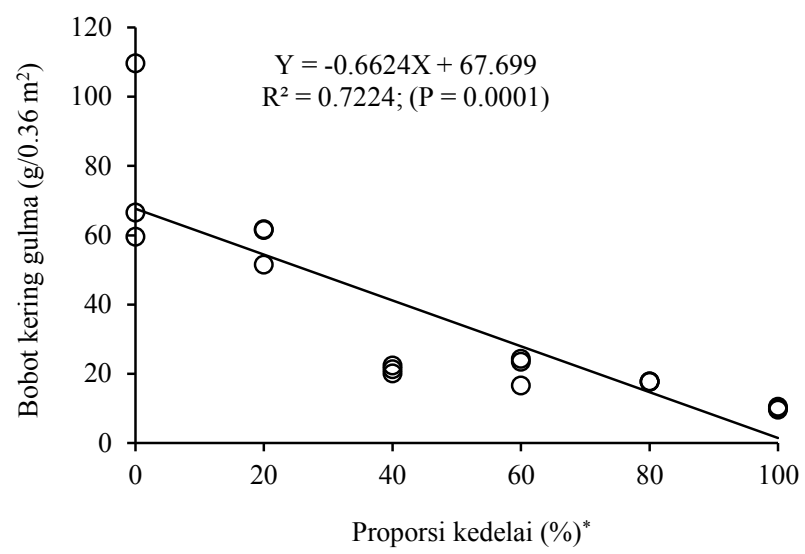

Gambar 4. Bobot kering total gulma pada beberapa pengaturan proporsi tanaman dalam sistem tumpangsari padi gogo dengan kedelai; "Proporsi kedelai 0\% (100:0), $20 \%(80: 20), 40 \%$ (60:40), 60\% (40:60), 80\% (20:80), dan $100 \%(0: 100)$

Badan Pusat Statistik. 2014. Statistik Lahan Pertanian Tahun 2009-2013. Pusat Data dan Sistem Informasi Pertanian, Sekretariat Jenderal-Kementerian Pertanian, Indonesia.

Badan Pusat Statistik. 2016. Proyeksi penduduk Indonesia 2010-2035. http://www.bps.go.id. [24 Maret 2016].

Chauhan, B.S., R.G. Singh, G. Mahajan. 2012. Ecology and management of weeds under conservation agriculture: A review. Crop Prot. 38:57-65.

Choudhary, V.K., A. Dixit, P.S. Kumar, B.S. Chauhan. 2014. Productivity, weed dynamics, nutrient mining, and monetary advantage of maize-legume intercropping in the Eastern Himalayan Region of India. Plant Prod. Sci. 17:342-352.

Downton, W.J.S. 1970. Preferential C4 - dicarboxylic acid synthesis, the postillumination $\mathrm{CO}_{2}$ burst, carboxyl transfer step, and grana configurations in plants with C4-photosynthesis. Can. J. Bot. 48:1795-1800. 
Eskandari, H., K. Kazemi. 2011. Weed control in maizecowpea intercropping system related to environmental resources consumption. Notulae Sci. Biol. 3:57-60.

Fitriana, M., Y. Parto, Munandar, D. Budianta. 2013. Pergeseran komposisi gulma akibat perlakuan bahan organik pada lahan kering bekas tanaman jagung (Zea mays L.). J. Agron. Indonesia 42:118-125.

Gao, Y., A.W. Duan, X.Q. Qiu, Z.G. Liu, J.S. Sun, J.P. Zhang. 2010. Distribution and use efficiency of photosynthetically active radiation in strip intercropping of maize and soybean. Agron. J. 102: 1149-1157.

Gharineh, M.H., S.A. Moosavi. 2010. Effect of intercropping (canola-faba bean) on density and diversity of weeds. Notulae Sci. Biol. 2:109-112.

Ilham, J. 2014. Identifikasi dan distribusi gulma di lahan pasir pantai Samas, Kabupaten Bantul, Daerah Istimewa Yogyakarta. Planta Tropika J. Agro Sci. 2:90-98.

Jamshidi, K., A.R. Yousefi, M. Oveisi. 2013. Effect of cowpea (Vigna unguiculata) intercropping on weed biomass and maize (Zea mays) yield. New Zealand J. Crop Hort. Sci. 1-8. DOI: 10.1080/01140671.201 3.807853 .

Kementerian Pertanian. 2017. Basis Data Statistik Pertanian: Produksi Nasional Tanaman Pangan Tahun 2014. http://aplikasi.pertanian.go.id/bdsp/hasil_kom.asp [28 Juli 2017].

Khan, M.A., K. Ali, Z. Hussain, R.A. Afridi. 2012. Impact of maize-legume intercropping on weeds and maize crop. Pak. J. Weed Sci. Res. 18:127-136.

Liu, X., T. Rahman, F. Yang, C. Song, T. Yong, J. Liu, C. Zhang, W. Yang. 2017. PAR interception and utilizationindifferentmaizeand soybeanintercropping patterns. PLoS ONE 12:1-17. doi:10.1371/journal. pone.0169218.

Mangoensoekarjo, S., A.T. Soejono. 2015. Ilmu Gulma dan Pengelolaan pada Budi Daya Perkebunan. Gadjah Mada University Press, Yogyakarta, Indonesia.
Marsal, D., K.P. Wicaksono, E. Widaryanto. 2015. Dinamika perubahan komposisi gulma pada tanaman tebu keprasan di lahan sistem reynoso dan tegalan. J. Produksi Tanaman 3:81-90.

Marsalis, M.A., S.V. Angadi, F.E. Contreas-Govea. 2010. Dry matter yield and nutritive value of corn, forage sorghum, and BMR forage sorghum at different plant populations and nitrogen rates. Field Crops Res. 116:52-57.

Onofri, A., E. Pannacci. 2014. Spreadsheet tools for biometry classes in crop science programmes. Comm. Biometry Crop Sci. 9:43-53.

Pasau, P., P. Yudono, A. Syukur. 2008. Pergeseran komposisi gulma pada perbedaan proporsi populasi jagung dan kacang tanah dalam tumpangsari pada tanah regosol Sleman. Ilmu Pertanian 16:60-78.

Rajiman, P. Yudono., E. Sulistyaningsih, E. Hanudin. 2008. Pengaruh pembenah tanah terhadap sifat fisik tanah dan hasil bawang merah pada lahan pasir pantai Bugel Kabupaten Kulon Progo. J. Agrin. 12:67-77.

Saparso, Tohari, D. Shiddieq, B. Setiadi. 2009. Anasir lingkungan penentu produksi kubis di lahan pasir pantai. J. Hort. 19:301-312.

Soejono, A.T. 2005.Tumpangsari tebu lahan kering dengan beberapa jenis tanaman palawija kaitannya dengan pertumbuhan gulma dan hasil tanaman. Disertasi. Sekolah Pascasarjana. Universitas Gadjah Mada. Yogyakarta.

Touré, A., J.M. Sogbedji, Y.M.D. Gumedzoé. 2013. The critical period of weed interference in upland rice in northern Guinea savanna: Field measurement and model prediction. African J. Agric. Res. 18:17481759.

Waller, S.S., J.K. Lewis. 1979. Occurrence of C3 and C4 photosynthetic pathways in North Amarican grasses. J. Range Manag. 32:12-28.

Yu, J., C. Zhan, Y. Li, D. Zhou, Y. Fu, X. Chu, Q. Xing, G. Han, G. Wang, B. Guan, Q. Wang. 2016. Distribution of carbon, nitrogen and phosphorus in coastal wetland soil related land use in the Modern Yellow River Delta. Sci. Rep. 6:1-9. DOI:10.1038/srep37940. 